\title{
SINTESIS BIODIESEL RUTE NON-ALKOHOL MENGGUNAKAN CANDIDA RUGOSA LIPASE DALAM BENTUK TERSUSPENSI
}

\author{
Heri Hermansyah*, Septhian Marno, Rita Arbianti, \\ Tania Surya Utami, dan Anandho Wijanarko \\ Departemen Teknik Kimia, Fakultas Teknik, Universitas Indonesia \\ Kampus Baru Ul-Depok 16424 \\ Email: heri@chemeng.ui.ac.id
}

\begin{abstract}
Abstrak
Sintesis biodiesel menggunakan biokatalis mampu memperbaiki kelemahan katalis alkali, yaitu tidak bercampur homogen, sehingga pemisahannya mudah dan mampu mengarahkan reaksi secara spesifik tanpa adanya reaksi samping yang tidak diinginkan. Namun penggunaan biokatalis di lingkungan beralkohol menyebabkan biokatalis terdeaktivasi secara cepat dan stabilitasnya menjadi buruk. Untuk menyelesaikan masalah tersebut, dalam riset ini diusulkan melakukan sintesis biodiesel melalui rute non-alkohol agar aktivitas dan stabilitas biokatalis tetap tinggi. Biokatalis yang digunakan adalah Candida rugosa lipase dalam bentuk tersuspensi. Metil asetat sebagai pensuplai gugus alkil direaksikan dengan trigliserida dari minyak kelapa sawit. Reaksi dilakukan dalam reaktor batch dan HPLC digunakan untuk menganalisa reaktan dan produk. Hasil penelitian menunjukkan bahwa lebih dari 86\% rantai asam lemak dari trigliserida minyak kelapa sawit berhasil di konversikan menjadi biodiesel pada kondisi konsentrasi biokatalis sebesar $4 \%$-wt substrat, rasio mol minyak:alkil sebesar 1:12 selama 50 jam reaksi. Selanjutnya, data kinetika menggunakan enzim tersuspensi juga ditunjukkan melalui profil konsentrasi tri-, di-, mono, dan biodiesel terhadap waktu selama 50 jam .
\end{abstract}

Kata Kunci: sintesis biodiesel, interesterifikasi, Candida rugosa lipase, rute non-alkohol, trigliserida

\begin{abstract}
Biodiesel synthesis using biocatalyst can improve the disadvantage of alkali catalyst. Biocatalysts are not homogeneously mixed, so its separation is easy and it is also able to direct the reaction specifically without any unwanted side reactions. However, the application of biocatalysts in alcoholic environment degrades the biocatalyst quickly, and its stability suffers. To solve this problem, this research proposes to perform biodiesel synthesis through a non-alcohol route so that the activity and stability of the biocatalyst can be preserved. The biocatalyst used was Candida rugosa lipase in suspended form. Methyl acetate which served as alkyl group source was reacted with triglycerides from palm oil. The reaction was performed in a batch reactor, and HPLC was used to analyze reactants and product concentrations. Research results indicated that more than $86 \%$ of fatty acid chains from the palm oil triglycerides were converted to biodiesel at a biocatalyst concentration of $4 \%$-wt of the substrate, oil:alkyl molar ratio of $1: 12$, and reaction period of 50 hours. Furthermore, the kinetic data obtained using suspended enzyme, were also shown by concentration profile of tri-, di-, monoglycerides and biodiesel versus time in 50 hours reaction time.
\end{abstract}

Keywords: biodiesel synthesis, interesterification, Candida rugosa lipase, non-alcohol route, triglyceride

*korespondensi 


\section{Pendahuluan}

Baru-baru ini biodiesel telah menarik perhatian sebagai sumber energi alternatif. Biodiesel (fatty acid methyl ester) telah diproduksi secara komersial melalui reaksi transesterifikasi minyak nabati dengan metanol menggunakan katalis alkali. Tetapi katalis alkali ini mempunyai beberapa kelemahan, seperti terjadinya reaksi pembentukan sabun akibat bereaksinya katalis (logam alkali) dengan asam lemak bebas. Selain itu katalis yang bercampur homogen juga mengakibatkan kesulitan dalam pemurnian produk. Proses pemurnian produk yang cukup sulit inilah yang pada akhirnya mengakibatkan harga biodiesel menjadi cukup mahal (Iso dkk., 2001).

Akhir-akhir ini mulai dikembangkan sintesis biodiesel menggunakan enzim lipase sebagai biokatalis. Lipase sebagai biokatalis mampu mengarahkan reaksi secara spesifik ke arah produk yang diinginkan tanpa terjadinya reaksi samping yang merugikan. Biokatalis ini merupakan katalis heterogen, sehingga pemisahannya dari produk setelah reaksi berakhir dapat dilakukan dengan mudah. Namun, enzim lipase mudah terdeaktivasi oleh alkohol yang merupakan reaktan dalam proses enzimatik sintesis biodiesel ini (Xu dkk., 2005). Oleh karena itu, perlu dikembangkan metode baru untuk meningkatkan aktivitas dan stabilitas lipase dalam proses sintesis biodiesel.

Metode baru yang akan dikembangkan adalah dengan mengubah rute reaksi dari menggunakan alkohol ke rute reaksi yang tidak menggunakan alkohol. Rute reaksi nonalkohol bisa dilakukan dengan cara mengganti alkohol dengan alkil asetat yang sama-sama berfungsi sebagai pensuplai alkil. Reaksi trigliserida dari minyak sawit dengan alkil asetat akan menghasilkan biodiesel (fatty acid alkil ester). Keberhasilan penelitian ini diharapkan dapat memberikan kontribusi pada peningkatan efisiensi sintesis biodiesel menggunakan lipase, sehingga sistem produksi biodiesel menggunakan katalis berbasis biokatalis bisa layak secara ekonomi untuk dikomersialkan di level industri.

Tahun 2002 Shimada dkk. melakukan sintesis biodisel menggunakan minyak sawit bekas dan Novozym 435 sebagai katalis melalui rute alkohol dengan metanol sebagai pendonor alkil (acyl-acceptor) dan diperoleh konversi 90\%. Baru pada tahun 2004 riset sintesis biodiesel melalui rute non-alkohol ini dilakukan oleh riset grup dari China dengan hasil 2 publikasi internasional (Du dkk., 2004; Xu dkk., 2004). Pada tahun 2004 Xu dkk. melakukan studi perbandingan antara sintesis biodiesel melalui rute alkohol dan rute nonalkohol menggunakan substrat minyak kedelai dan Novozym 435 sebagai biokatalis. Dari penelitian tersebut, diperoleh \% yield metil ester mencapai 92\%.

Penelitian dilanjutkan oleh Du dkk. pada tahun 2004 dengan melalukan pemodelan kinetika terhadap lipase dalam mengkatalis reaksi interesterfikasi sintesis biodiesel rute non-alkohol menggunakan pemodelan Ping Pong Bi Bi. Dalam penelitian ini reaksi sintesis biodiesel yang dilakukan adalah dari minyak sawit melalui rute non alcohol menggunakan biokatalis lipase Candida rugosa powder dalam bentuk tersuspensi. Penelitian ini berada pada tahap reaktor batch dengan menggunakan biokatalis tersuspensi. Candida rugosa lipase memiliki aktivitas yang tinggi dalam mengkonversi trigliserida menjadi berbagai produk turunan melalui berbagai rute reaksi (Hung dkk., 2003).

\section{Metodologi}

Secara umum penelitian ini terdiri dari beberapa tahap utama :

\section{Skrining biokatalis}

Pada tahap skrining biokatalis akan dikumpulkan pustaka mengenai jenis lipase terbaik yang digunakan ntuk sintesis biodiesel rute non-alkohol serta mengenai kondisi operasi optimal untuk reaksi sintesis biodiesel rute non-alkohol baik dari buku, jurnal, maupun artikel. Dari hasil studi pustaka ini diharapkan diperoleh tinjauan pustaka yang dapat digunakan sebagai dasar dari reaksi sintesis biodiesel rute non-alkohol.

\section{Sintesis biodiesel menggunakan Candida rugosa lipase dalam bentuk tersuspensi}

Proses penelitian yang dilakukan adalah mengetahui aktivitas biokatalis dilihat dari pengaruh konsentrasi biokatalis terhadap produk FAME atau methyloleat (Gambar 3) dan waktu optimum terbentuknya FAME (metiloleat) dilihat dari profil laju reaksi pembentukannya (Gambar 7).

Tahapan reaksi sintesis biodiesel dapat dilihat pada Gambar 1. Tahapan pertama adalah membuat larutan lipase dalam bentuk tersuspensi, yaitu dengan melakukan 
pencampuran antara lipase dengan metalasetat, kemudian dilakukan pengadukan selama $\mathrm{t}=30-45$ menit pada $\mathrm{T}=25-30^{\circ} \mathrm{C}$. Tahapan berikutnya adalah reaksi interesterifikasi, yaitu larutan lipase tersuspensi direaksikan dengan minyak kelapa sawit yang berlangsung dalam reaktor batch (labu Erlenmeyer $25 \mathrm{~mL}$ ) pada suhu $37^{\circ} \mathrm{C}$ selama 50 jam. Skema reaktor batch dapat dilihat pada Gambar 2. Selanjutnya sampel diambil sesuai dengan waktu yang telah ditentukan. Terakhir, sampel dianalisa menggunakan HPLC (high performance liquid chromatography).

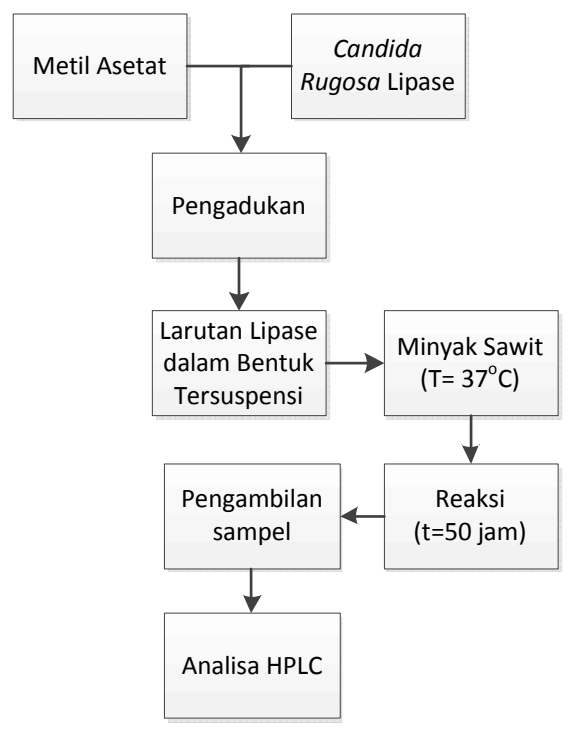

Gambar 1. Diagram alir penelitian sintesis biodiesel rute non-alkohol

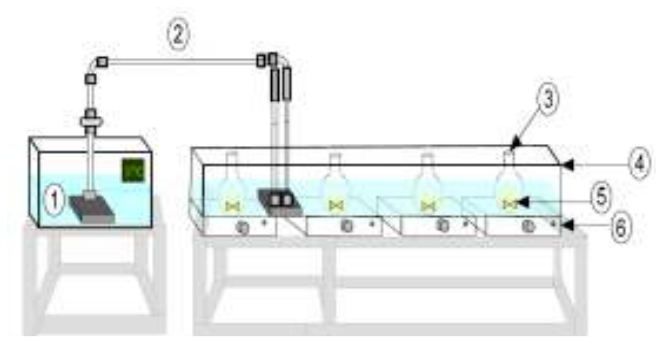

Keterangan :

1. Water bath, 2. Rangkaian Pompa

Air, 3.Erlenmeyer $25 \mathrm{~mL}$, 4. Wadah

Air (Tupper Ware), 5. Bar Stirrer, 6. Magnetic stirrer

Gambar 2. Skematik reaktor batch interesterifikasi sintesis biodiesel secara enzimatik
Kondisi reaksi interesterifikasi biodiesel dapat dilihat pada Tabel 1 . Perbandingan mol substrat minyak kelapa sawit terhadap metil asetat yang digunakan adalah 1:12. Percobaan uji aktivitas ini direaksikan pada suhu $37^{\circ} \mathrm{C}$. Konsentrasi free enzim yang digunakan adalah 1\%, 2\%, dan 4 $\%$-wt dari substrat campuran minyak sawit dan metil asetat. Hanya untuk konsentrasi biokatalis sebesar $4 \%$-wt dibuat profil laju reaksi (mol/L) terhadap waktu. Pengambilan sampel untuk membuat profil laju reaksi dilakukan pada t (jam): 0, 0,25, 0,5, 1, 2, 4, 6, 9, $12,15,20,25,30,35,40,45$, dan 50 .

Tabel 1. Kondisi operasi untuk reaksi lipase dalam bentuk tersuspensi

\begin{tabular}{ll}
\hline \multicolumn{1}{c}{ Deskripsi } & \multicolumn{1}{c}{ Uraian } \\
\hline Konsentrasi awal enzim & 1,2 dan 4 \\
& {$[\%$-wt } \\
& $\begin{array}{l}\text { campuran } \\
\text { reaktan }]\end{array}$ \\
& $1: 3$ dan $1: 12$ \\
Rasio molar minyak & \\
sawit: metal asetat & $37 \circ \mathrm{C}$ \\
Temperatur reaksi & 50 jam \\
Waktu reaksi & \\
\hline
\end{tabular}

Konsentrasi yang dianalisa adalah konsentrasi FAME atau metiloleat (mol/L), Dengan mengetahui profil laju konsentrasi pembentukan metiloleat maka dapat diketahui profil laju konsentrasi dari trioleat (Gambar 4), dioleat (Gambar 5), dan monooleat (Gambar 6) menggunakan neraca massa reaksi. Hal ini guna mengetahui korelasi profil laju reaksi (mol/L) terhadap waktu (jam) semua konsentrasi tri, di, mono, dan methyloleat ( Gambar 8).

\section{Hasil dan Pembahasan}

\section{Hasil sintesis biodiesel menggunakan Candida rugosa lipase dalam bentuk tersuspensi}

Dalam percobaan ini reaksi yang dilakukan berlangsung melalui rute nonalkohol, yaitu minyak sawit akan direaksikan dengan metil asetat sebagai pensuplai gugus alkil dalam reaksi interesterifikasi. Dari Gambar 3 terlihat bahwa semakin besar konsentrasi biokatalis yang digunakan maka produk yang dihasilkan akan semakin besar. Hasil ini sesuai terhadap prinsip mekanisme reaksi enzimatik pada umumnya dimana jumlah konsentrasi biokatalis berbanding lurus terhadap produk yang dihasilkan. Dari kurva tersebut juga terlihat bahwa dengan 
penggunaan substrat yang lebih besar maka produk yang dihasillkan juga akan semakin besar.

Dari profil konsentrasi yang terbentuk maka dapat dilihat nilai konsenstrasi biodiesel yang tertinggi, yaitu sebesar 4,25 mol/L, terbentuk saat rasio mol reaktan 1:12 dan konsentrasi biokatalis adalah 4 \%-wt. Dari tahapan ini akan terlihat bahwa ada pengaruh penggunaan substrat dan biokatalis yang digunakan terhadap jumlah produk yang dihasilkan. Dengan kata lain, adanya penambahan substrat dalam reaksi insteresterifikasi ini belum menurunkan kemampuan enzim dalam mengkatalisis pembentukan produk, ini berarti kemampuan enzim untuk mengikat substrat belum mencapat titik jenuhnya sehingga dengan kata lain ada kemungkinan produk yang dihasilkan akan semakin besar seiring dengan bertambahnya substrat.

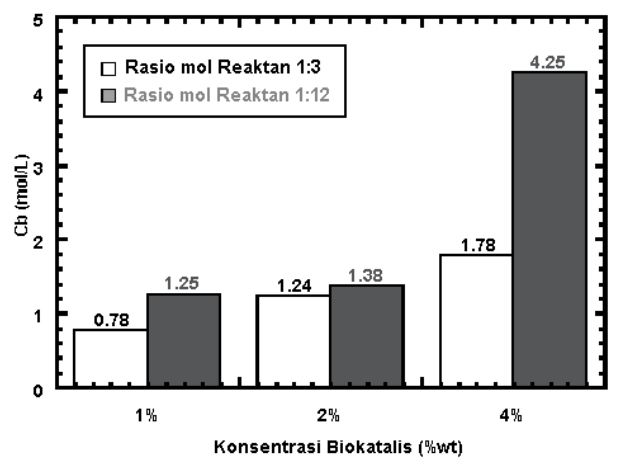

Gambar 3. Pengaruh konsentrasi biokatalis terhadap konsentrasi biodiesel (mol/L) yang dihasilkan pada perbedaan rasio reaktan menggunakan Candida rugosa dalam bentuk tersuspensi (t=50jam; $\mathrm{T}=37^{\circ} \mathrm{C}$ )

Untuk mengetahui profil konsentrasi masing-masing komponen maka dalam penelitian ini dilakukan variasi waktu. Berikut adalah hasil sintesis biodiesel menggunakan Candida rugosa lipase dalam bentuk tersuspensi.

Dari Gambar 4 terlihat bahwa dari laju reaksi trioleat yang terbentuk maka terlihat bahwa konsentrasi dari trioleat (mol/L) mengalami penurunan seiring meningkatnya waktu. Penurunan konsentrasi trioleat dikarenakan adanya sejumlah substrat yang membentuk menjadi produk (biodiesel). Peningkatan jumlah produk yang terbentuk terlihat dari meningkamya konsentrasi dari biodiesel (mol/L) seiring bertambahnya waktu.

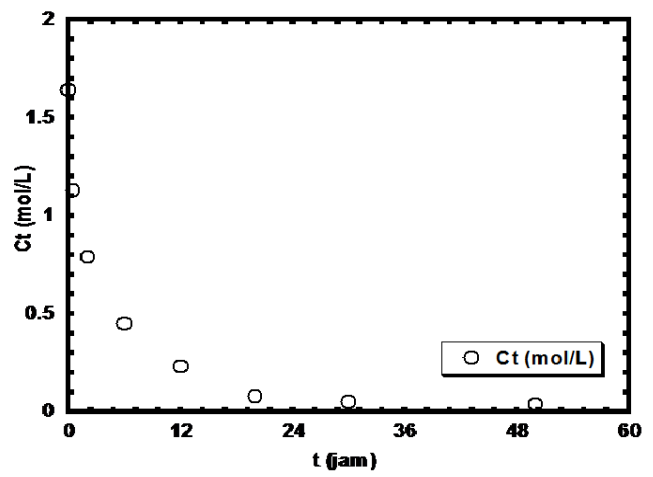

Gambar 4. Profil konsentrasi trioleat (mol/L) versus variasi waktu menggunakan Candida rugosa lipase dalam bentuk tersuspensi $\quad(t=50$ jam; $\mathrm{T}=37^{\circ} \mathrm{C}$; Rasio mol reaktan=1:12)

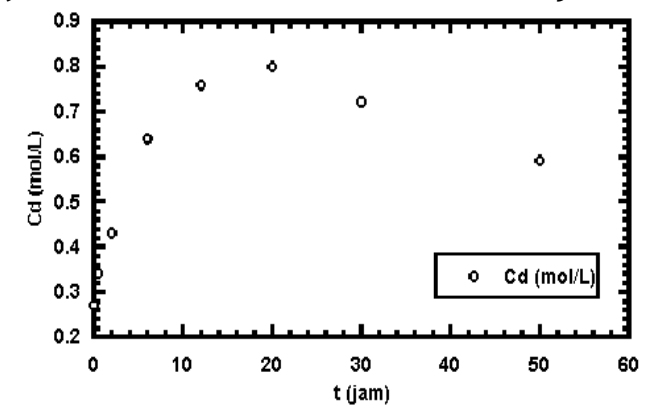

Gambar 5. Profil konsentrasi dioleat (mol/L) versus variasi waktu menggunakan Candida rugosa lipase dalam bentuk tersuspensi $(t=50$ jam; $T=$ $37^{\circ} \mathrm{C}$; Rasio mol reaktan 1:12)

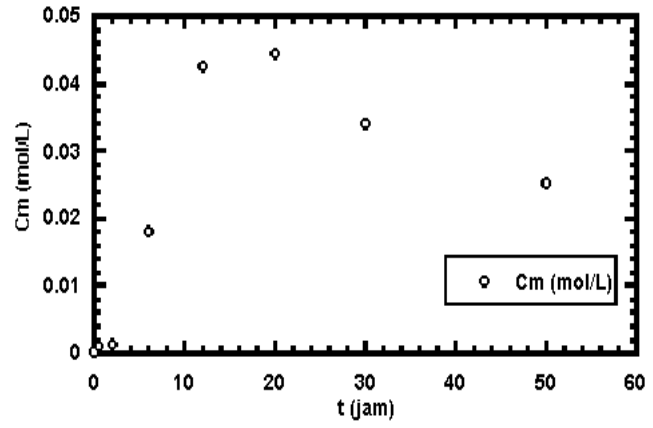

Gambar 6. Profil konsentrasi monooleat (mol/L) versus variasi waktu menggunakan Candida rugosa lipase dalam bentuk tersuspensi $(t=50$ jam; $T=$ $37^{\circ} \mathrm{C}$; Rasio mol reaktan $=1: 12$ )

Konsentrasi zat intermediet, dioleat (Gambar 5) dan monooleat (Gambar 6), selama reaksi selalu rendah. Hal ini karena 
kedua zat intermediet tersebut tidak terakumulasi tetapi masing-masing langsung bereaksi kembali untuk membentuk zat baru. yaitu monooleat dan triasetilgliserol. Konsentrasi dioleat hanya menunjukkan kenaikan sedikit pada awal reaksi untuk kemudian menurun kembali setelahnya.

Dari Gambar 7 terlihat bahwa konsentrasi biodiesel yang terbentuk paling besar terjadi saat $\mathrm{t}=50$ jam, yaitu mencapai 4,25 mol/L dengan konversi yang dihasilkan mencapai 86,55\%. Menurut persamaan tentang laju reaksi pembentukan produk maka produk yang terbentuk seharusnya akan semakin besar jika waktu reaksi yang digunakan semakin lama.

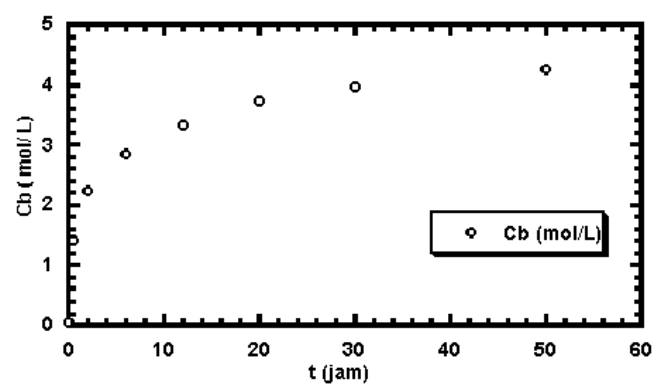

Gambar 7. Profil konsentrasi methyloleat (mol/L) versus variasi waktu menggunakan Candida rigosa lipase dalam bentuk tersuspensi $\left(t=50\right.$ jam; $T=37^{\circ} \mathrm{C}$; Rasio mol reaktan $=1: 12$ )

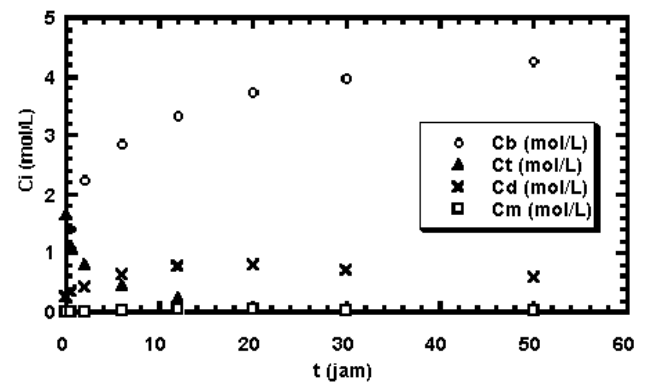

Gambar 8. Laju konsentrasi masing-masing komponen (mol/L) dalam raksi interesterfikasi sintesis biodiesel menggunakan Candida rugosa lipase dalam bentuk tersuspensi $(t=50$ jam; $T=$ $37^{\circ} \mathrm{C}$; Rasio $\mathrm{mol}$ reaktan $=1: 12$ )

Waktu optimum yang didapat dalam penelitian ini adalah saat $\mathrm{t}=50$ jam karena berhasil mengkonversi $86,55 \%$ trioleat membentuk methyl oleat sebesar 4,25 mol/L. Dari Gambar 7 terlihat trend data yang cenderung linier setelah $\mathrm{t}=50$ jam., sehingga dapat dikatakan $\mathrm{t}=50$ jam merupakan waktu optimum dalam penelitian ini. Dalam penelitian ini belum dianalisa lebih lanjut konsentrasi methyloleat di atas $\mathrm{t}=50$ jam.

Terlihat dari Gambar 8 bahwa terdapat korelasi laju reaksi semua komponen, yaitu seiring meningkatnya jumlah produk (methyloleat) maka terjadi penurunan konsentrasi substrat (trioleat), disertai dengan terjadinya pembentukan komponen dioleat, dan monooleat terlebih dahulu.

\section{Kesimpulan}

1. Konsentrasi biodiesel tertinggi dalam penelitian ini adalah sebesar 4,25 mol/L dengan konversi trioleat yang dihasilkan sebesar $86,55 \%$.

2. Semakin lama waktu reaksi maka laju pembentukan ke arah produk yang dihasilkan akan semakin besar.

3. Peningkatan jumlah konsentrasi biokatalis berpengaruh terhadap peningkatan konsentrasi biodiesel yang dihasilkan. Sehingga semakin besar jumlah biokatalis yang digunakan maka produk (biodiesel) yang dihasilkan akan semakin besar.

4. Untuk kasus reaksi selama 50 jam enzim masih memiliki aktivitas yang baik dalam mengkonversi trigliserida menjadi biodiesel. Namun aktivitas enzim setelah 50 jam belum diselidiki lebih lanjut untuk menyelidiki faktor-faktor yang mempengaruhi deaktivasi enzim.

\section{Daftar Notasi dan Simbol}

$\begin{array}{ll}\mathrm{mg} / \mathrm{L} & \text { miligram/Liter } \\ \mathrm{gr} / \mathrm{mL} & \text { Gram/Liter } \\ \mathrm{mol} / \mathrm{L} & \text { Mol/liter } \\ \mathrm{T}\left({ }^{\circ} \mathrm{C}\right) & \text { Suhu }\left({ }^{\circ} \mathrm{C}\right) \\ \mathrm{t}(\mathrm{jam}) & \text { Waktu (jam) } \\ \mathrm{t}(\text { detik) } & \text { Waktu (detik) } \\ \mathrm{Ct} & \text { Konsentrasi trioleat } \\ \mathrm{Cd} & \text { Konsentrasi dioleat } \\ \mathrm{Cm} & \text { Konsentrasi monooleat } \\ \mathrm{Cb} & \text { Konsentrasi biodiesel } \\ \mathrm{wt} & \text { (Methyl-oleat) } \\ & \text { (weight) }\end{array}$

\section{Daftar Pustaka}

Du, W.; Xu, Y.; Liu, D.; Zeng J.,Comparative study on lipase-catalyzed transformation of soybean oil for biodiesel production with different acyl acceptors, Journal of Molecular 
Catalysis B: Enzymatic, 2004, Vol. 30(3-4), 125-129.

Shimada, Y.; Watanabe, Y.; Sugihara, A.; Tominaga, Y., Enzymatic alcoholysis for biodiesel fuel production and application of the reaction to oil processing, Journal of Molecular Catalysis B: Enzymatic, 2002, Vol. 17(3-5), 133-142.

$\mathrm{Xu}$, Y.; Du, W.; Liu, D., Study on the kineties of enzymatic interesterification of triglycerides for biodiesel production with methyl acetate as the acyl acceptor, Journal of Molecular
Catalysis B: Enzymatic, 2005, Vol. 32 (5-6), 241-245.

Iso, M.; Chen, B.; Eguchi, M.; Kudo, T.; Shretha, S., Production of biodiesel fuel from triglycerides and alcohol using immobilized lipase, Journal of Molecular Catalysis B: Enzymatic, 2001, Vol. 16(1), 53-58.

Hung, T.; Giridhar, R.; Chiou, S.; Wu, W., Binary immobilization of Candida rugosa lipase on chitosan, Journal of Molecular Catalysis B: Enzymatic, 2003, Vol. 26(1-2), 69-78. 